Analisis Penalaran Matematis....(Fajar Falbiansyah, Heni Pujiastuti)

\title{
ANALISIS PENALARAN MATEMATIS MAHASISWA PADA MATERI GEOMETRI BERDASARKAN TEORI VAN HIELE
}

\author{
Oleh: Fajar Falbiansyah, Heni Pujiastuti \\ Email : 2225170050@untirta.ac.id \\ (Universitas Sultan Ageng Tirtayasa)
}

\begin{abstract}
Abstrak
Penelitian ini bertujuan untuk mengetahui sejauh mana tingkat penalaran matematis mahasiswa pada materi geometri berdasarkan teori Van Hiele. Subjek penelitian ini adalah mahasiswa FKIP Universitas Sultan Ageng Tirtayasa. Subjek penelitian dipilih dengan menggunakan Teknik purposive sampling. Jumlah sampel yang diperlukan berjumlah 3 orang masing-masing dari angkatan 2017, 2018, dan 2019 yang dipilih berdasarkan kriteria tertentu yaitu memiliki kemampuan penalaran matematis dan komunikasi matematis yang baik serta mau dan mampu mengerjakan soal yang diberikan. Teknik pengumpulan data yang dilakukan yaitu dengan pemberian tes, instrument tes yang digunakan berdasarkan tingkat geometri Van Hiele serta memuat indicator penalaran matematis. Hasil penelitian ini menunjukkan bahwa dua subjek berada dalam level geometri tingkat 5 (Rigor) serta satu subjek berada pada level geometri tingkat 4 (Deduksi Formal), ketiga subjek juga mampu mencapai setiap indikator yang termuat di dalam soal.
\end{abstract}

Kata Kunci: Penalaran Matematis, Van Hiele, Geometri

\section{ANALYSIS OF STUDENT MATHEMATICAL REASONING ON GEOMETRY MATERIALS BASED ON VAN HIELE THEORY}

\begin{abstract}
This study aims to determine the extent of students' mathematical reasoning on geometry based on Van Hiele's theory. The subjects of this study were students of FKIP Sultan Ageng Tirtayasa University. The research subjects were selected using purposive sampling technique. The number of samples needed is 3 people each from the class of 2017, 2018, and 2019 who were selected based on certain criteria, namely having good mathematical reasoning abilities and good mathematical communication and willing and able to do the given problem. Data collection techniques were carried out by providing tests, test instruments used based on the level of Van Hiele geometry and loading indicators of mathematical reasoning. The results of this study indicate that two subjects are at level 5 geometry (Rigor) and one subject is at level 4 geometry (Formal Deduction), all three subjects are also able to reach each indicator contained in the problem.
\end{abstract}

Keywords: Mathematical Reasoning, Van Hiele, Geometry 


\section{A. PENDAHULUAN}

Salah satu materi yang terus dipelajari mulai dari jenjang sekolah hingga jenjang perguruan tinggi adalah matematika. Matematika merupakan materi yang sangat penting dalam kehidupan. Berbagai jenis kegiatan ataupun pekerjaan membutuhkan matematika (Adamura \& Susanti, 2018). Pendidikan di sekolah serta di perguruan tinggi pada pelajaran matematika peserta didik dituntut untuk mempunyai daya nalar yang baik pada saat menyelesaikan masalah yang berkaitan dengan matematika (Nadhifa et al., 2019).

Penalaran adalah aspek yang sangat penting dari kemampuan matematika dalam pengajaran dan pembelajaran matematika (Sukirwan et al., 2018). Penalaran matematis merupakan salah satu kemampuan matematis yang sangat penting dalam proses pembelajaran matematika. Karena matematika merupakan suatu ilmu pengetahuan yang diperoleh melalui bernalar (Mikrayanti, 2016).

Pada dasarnya setiap penyelesaian soal matematika diperlukannya kemampuan penalaran. Melalui penalaran, diharapkan dapat memahami dan menilai bahwa matematika merupakan kajian yang masuk akal atau logis (Agustin, 2016). Kemampuan penalaran matematis yaitu kemampuan menghubungkan permasalahan-permasalahan ke dalam suatu ide atau gagasan sehingga dapat menyelesaikan permasalahan matematis (Konita et al., 2019).

Kemampuan penalaran matematis ini menjadi penting dan sangat diperlukan oleh mahasiswa matematika maupun Pendidikan matematika karena bukan hanya berfungsi untuk melatih kemampuan berpikir mahasiswa saja, tapi juga penalaran memiliki peran penting dalam matematika karena dijadikan sebagai pondasi bagi standar proses lainnya. Selain itu, penalaran dan matematika tidak dapat dipisahkan satu sama lain karena dalam menyelesaikan permasalahan matematika memerlukan penalaran sedangkan kemampuan penalaran dapat dilatih dengan belajar matematika (Kusumawardani, 2018).

Salah satu cabang matematika yang sangat erat kaitannya dengan kehidupan sehari hari yaitu geometri. Geometri adalah salah satu cabang ilmu matematika. Geometri berasal dari bahasa Yunani yaitu geo yang berarti bumi dan metria yang berarti ukuran (Hodiyanto, 2018). Dalam kurikulum matematika yang 
membahas mengenai geometri adalah pada bagian yang membahas mengenai bangun datar, bangun ruang, sudut dan sebagainya. Sedangkan pada tingkat pendidikan tinggi (perguruan tinggi) geometri merupakan salah satu mata kuliah yang diajarkan pada program studi pendidikan matematika (Nasional, 2009).

Geometri dapat dilihat secara nyata dikehidupan sehari-hari dalam bentuk benda sekitar misalnya pintu rumah, jendela, ubin, buku, jam dinding dan lainnya (Yuliana \& Ratu, 2019). Setiap teorema, dalil, dan pernyataan matematis dalam Geometri memerlukan suatu bukti yang diperoleh melalui proses pembuktian.

Oleh karenanya, kemampuan dalam menyusun bukti matematis sangat diperlukan mahasiswa pada materi ini, namun untuk menyusun bukti matematis, perlu adanya kemampuan penalaran matematis yang memadai sehingga dalam menyusun pembuktian akan lebih mudah jika seorang mahasiswa memiliki tingkat penalaran matematis yang tinggi (Mahfudy, 2017).

Salah satu teori belajar yang dapat digunakan untuk proses pembelajaran geometri yaitu teori belajar Van Hiele. Teori belajar Van Hiele merupakan suatu teori belajar yang menyesuaikan dengan tingkat kognitif atau pemahaman peserta didik dalam belajar geometri (Fertiwi et al., 2013). Teori belajar Van Hiele menjelaskan bahwa mahasiswa akan melalui tahapan perkembangan berpikir dalam pembelajaran geometri di lima tingkat: 1) Tingkat visualisasi, 2) Tingkat analisis, 3) Tingkat abstraksi (deduksi informal), 4) Tingkat deduksi formal, dan 5) Tingkat Ketepatan (Rigor) (Yuliana \& Wiryawan, 2018).

\section{B. METODOLOGI PENELITIAN}

Jenis penelitian yang digunakan dalam penelitian ini yaitu penelitian deskriptif kualitatif. Subjek penelitian ini adalah mahasiswa jurusan Pendidikan Matematika FKIP Universitas Sultan Ageng Tirtayasa. Subjek penelitian dipilih dengan menggunakan teknik purposive sampling, Jumlah sampel yang diperlukan berjumlah 3 orang masing masing dari angkatan 2017, 2018, dan 2019 yang telah dipilih berdasarkan kriteria tertentu, yaitu subjek memiliki kemampuan penalaran matematis dan komunikasi matematis yang baik serta subjek mau dan mampu mengerjakan soal yang diberikan. 
Teknik pengumpulan data yang dilakukan pada penelitian ini adalah dengan pemberian tes, Instrumen dalam penelitian ini berupa soal tes yang berdasarkan level geometri teori Van Hiele dan indikator penalaran matematis. Soal tes terdiri dari 5 soal Uraian dengan masing-masing soal memiliki tingkatan yang berbeda-beda berdasarkan dengan teori Van Hiele dan masing masing soal memiliki indikator kemampuan penalaran matematis. Teknik analisis data dalam penelitian ini yaitu pengumpulan data, penyajian data disajikan dalam tulisan yang disusun secara sistematis serta menggunakan Bahasa yang mudah untuk dipahami agar pembaca tidak kebingungan dalam mengamati hasil penelitian ini.

\section{HASIL PENELITIAN DAN PEMBAHASAN}

Hasil pengerjaan dari 3 subjek penelitian yang berbeda memiliki jawaban yang hampir serupa, beberapa perbedaan juga begitu terlihat diiantara jawaban ketiga subjek juga hasil yang diperoleh dalam jawaban pun terlihat perbedaannya.

\section{Deskripsi jawaban dari subjek A (Angkatan 2017)}

\section{Soal Nomor 1 :}

1. Dari gambar disamping, sebutkan segitiga-segitiga yang tergambar tersebut! Serta sebutkan yang mana yang merupakan segitiga:

i) lancip

ii) siku-siku

iii) tumpul

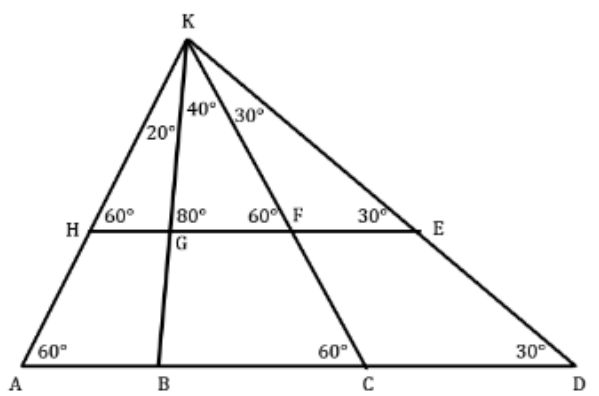

Jawaban:

1) Lancip: AKB, BKC, CKD, HKG, GKF, FKE,

II) Siku-siku: AKD

III) Tumpul: ABK, HGK, KFE, KCD.

\section{Gambar 1. Jawaban Subjek A Soal Nomor 1}

Berdasarkan jawaban yang diberikan oleh subjek A padan soal nomor 1, terlihat bahwa subjek A dapat menyebutkan jumlah segitiga yang tercantum dalam gambar, hanya saja ada sedikit kekurangan jumlah segitiganya, yaitu pada segitiga siku-siku, subjek A hanya menyebutkan 1 saja, padahal sebenarnya ada 2 segitiga siku-siku didalam gambar, yaitu segitiga HKD. Dari hasil jawaban ini 
Analisis Penalaran Matematis....(Fajar Falbiansyah, Heni Pujiastuti)

juga terlihat bahwa subjek A sudah dapat menemukan sifat serta perbedaan yang mana sudut lancip, sudut siku-siku, sudut tumpul. Jadi pada tahap visualisasi ini subjek A sudah baik, dengan hanya melihat gambar sudah dapat mengetahui perbedaan serta bentuk gambarnya seperti apa.

\section{Soal Nomor 2 :}

2. Beri alasan mengapa segitiga dibawah ini disebut segitiga siku-siku sama kaki.

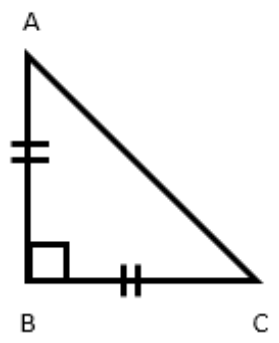

Jawaban:

Karena ukuran sudut $B$ segitiga $A B C$ yaitu $90^{\circ}$ dan sisi $A B$ dan $B C$

Mempunyai panjang yang sama / kongruen

Gambar 2. Jawaban Subjek A Soal Nomor 2

Berdasarkan hasil jawaban yang diberikan oleh subjek A pada soal nomor 2, terlihat bahwa subjek A sudah dapat memberikan alasan atau bukti dari suatu pernyataan dengan tepat, deskripsinya pun singkat namun jawabannya benar. Jadi pada tahap analisis ini subjek A dapat menganalisis soal serta memberikan alasan dan bukti yang tepat.

\section{Soal Nomor 3 :}

3. Jika diketahui $\overline{A E} \cong \overline{E B}$ dan $\overline{D E} \cong \overline{E C}$ Benar/salah kalimat berikut dan berikan alasannya

a. $\overline{A E}=\overline{E B}$

b. $\mathrm{DE}=\mathrm{EC}$

c. E titik tengah $\overline{A B}$

d. Jika $\mathrm{CD}=20$ dan $\mathrm{AB}=40$ maka $\overline{B E} \cong \overline{C D}$ Jawaban:

A. Salah, yang benar yaitu: $u$. sudut $\overline{A E}=u$. sudut $\overline{E B}$

B. Salah

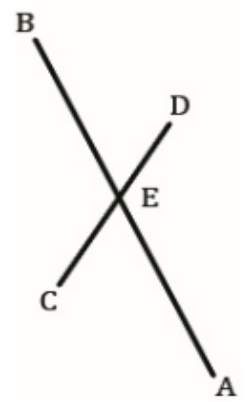

C. Benar, karena $\overline{A E} \cong \overline{E B}$

D. Benar

\section{Gambar 3. Jawaban Subjek A Soal Nomor 3}

Berdasarkan jawaban yang diberikan oleh subjek A pada soal nomor 3, pada bagian a subjek A dapat menyatakan jawaban dengan benar, namun subjek 
A tidak memberi alasan mengapa kalimatnya salah tetapi subjek A memberikan solusinya harusnya yang benar seperti apa. Pada bagian b subjek A hanya menyatakan benar atau salah saja, namun tidak disertai alasan serta buktinya mengapa kalimatnya benar. Pada bagian c subjek A dapat menyatakan jawaban yang benar, serta memberikan alasan mengapa kalimatnya benar. Lalu yang terakhir pada bagian d sama seperti bagian $b$, subjek A hanya menyebutkan benar atau salah saja, tidak memberikan alasan atau bukti nya mengapa kalimatnya benar. Jadi pada tahap ini subjek A masih kurang mampu dalam memperoleh intisari dari konsep soal yang diberikan.

\section{Soal Nomor 4 :}

4. Diketahui $A B C$ merupakan sudut tumpul, ukuran sudut $A B D>$ ukuran sudut $A B C$ Buktikan jika ABD merupakan sudut tumpul.

Jawaban:

Diketahui:

$A B C$ merupakan sudut tumpul, ukuran sudut $A B D>$ ukuran sudut $A B C$

Akan dibuktikan:

ABD merupakan sudut tumpul

Andaikan ABD bukan merupakan sudut Tumpul ( sudut lancip atau sudut siku siku ), maka ukuran

sudut $A B D$ < ukuran sudut $A B C$, kontradiksi dengan hipotesis awal yaitu ukuran sudut $A B D>$ ukuran sudut ABC. Sehingga dapat disimpulkan bahwa ABD merupakan sudut tumpul.

\section{Gambar 4. Jawaban Subjek A Soal Nomor 4}

Berdasarkan jawaban yang diberikan oleh subjek A pada soal nomor 4, subjek A terlihat dapat mengajukan dugaan serta memberikan bukti dengan kontradiksi, artinya subjek A menduga atau memberikan pengandaian terlebih dahulu jika sudut ABD merupakan sudut lancip, sehingga hasilnya bertentangan dengan pernyataan di soal yang menyatakan bahwa ukuran sudut $\mathrm{ABC}>90^{\circ}$ dan ukuran sudut $\mathrm{ABD}>$ ukuran sudut $\mathrm{ABC}$, namun kurangnya pada jawaban subjek A yaitu tidak memberikan ilustrasi gambar sudutnya, tetapi jawabannya tepat. Pada tahap ini juga subjek A sudah baik dalam memberikan kesimpulan yang tepat dari pernyataan yang diberikan di dalam soal. 


\section{Soal Nomor 5 :}

5. Diketahui sudut PQR, $\overline{Q T}$ garis bagi sudut $P Q R, \overline{Q U}$ garis bagi sudut $P Q T$, Jika ukuran sudut $P Q U=18^{\circ}$, maka ukuran sudut $P Q R=\ldots$

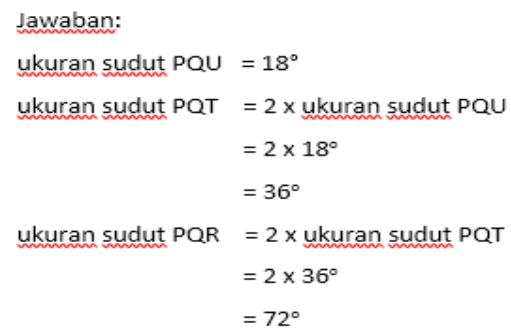

\section{Gambar 5. Jawaban Subjek A Soal Nomor 5}

Berdasarkan jawaban yang diberikan oleh subjek A pada soal nomor 5, subjek A terlihat dapat melakukan manipulasi matematik dengan baik, hal ini dapat dilihat ketika subjek A melakukan perhitungan sehingga mendapatkan hasil yang diharapkan, subjek A juga terlihat sudah mengetahui sifat dari garis bagi sudut, namun disini subjek A kurang memberikan penjelasan mengapa ukuran sudut $\mathrm{PQT}=2 \mathrm{x}$ ukuran sudut $\mathrm{PQU}$ dan juga mengapa ukuran sudut $\mathrm{PQR}=2 \mathrm{x}$ ukuran sudut PQT, serta tidak ada ilustrasi gambar yang diberikan oleh subjek A sehingga subjek A tidak memberikan dugaan. Pemberian alasan dan buktinya sudah cukup baik, deskripsinya tidak terlalu panjang, hanya saja tidak dilengkapi dengan generalisasi atau penarikan kesimpulan secara umum, tetapi hasil perhitungannya sudah tepat.

\section{Deskripsi jawaban dari subjek B (Angkatan 2018)}

\section{Soal Nomor 1 :}

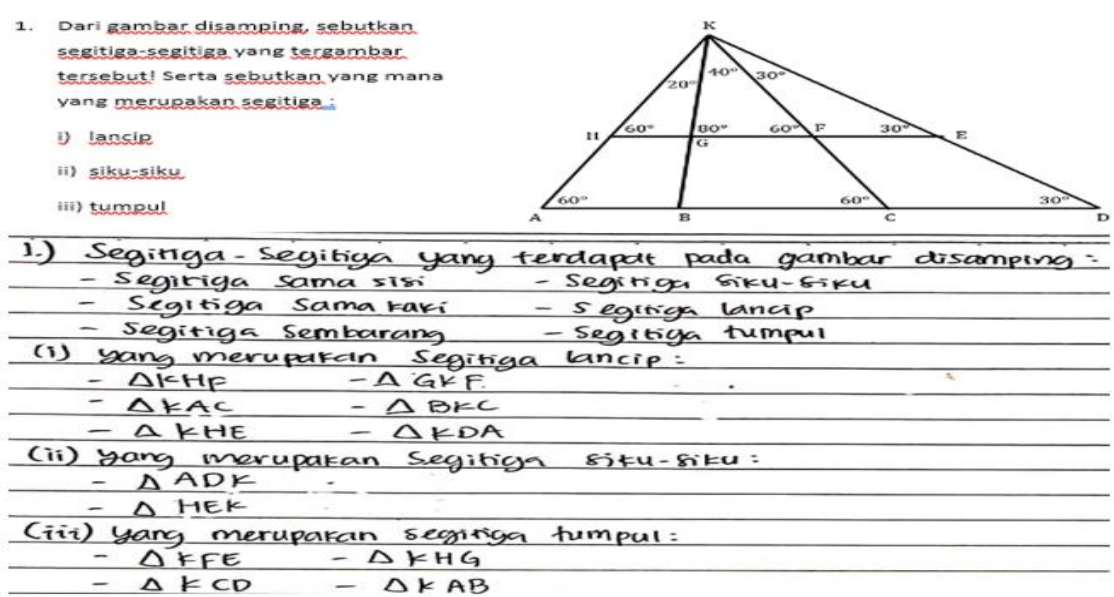

Gambar 6. Jawaban Subjek B Soal Nomor 1 
Berdasarkan jawaban yang diberikan oleh subjek B pada soal nomor 1, terlihat bahwa subjek B sudah dapat menentukan jumlah segitiga yang ada pada gambar, serta subjek juga dapat menyebutkan yang mana sudut lancip, sudut sikusiku, dan sudut tumpul dengan tepat. Pada tahap visualisasi ini subjek B sudah sangat baik dalam mengetahui, menentukan serta menyebutkan apa yang dilihat dari soal dan gambar.

\section{Soal Nomor 2 :}

2. Beri alasan mengapa segitiga dibawah ini disebut segitiga siku-siku sama kaki.

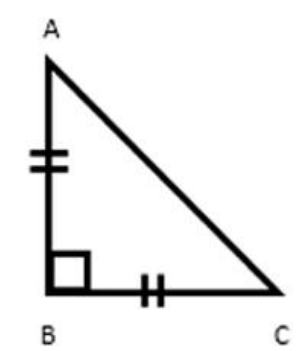

2.) Karena kedua sisnya sama panjing dan sach Satu sudvenga merupakan sudut siku-siku $\left(90^{\circ}\right)$. Pada gambar, $\triangle B C A$ siku-fiku ditint $B$, dencyan $B A=B C$.

\section{Gambar 7. Jawaban Subjek B Soal Nomor 2}

Berdasarkan jawaban yang diberikan oleh subjek B pada soal nomor 2, terlihat bahwa subjek B tampaknya sudah baik dalam menganalisis soal, hal ini dapat dilihat dari hasil jawaban yang memberikan alasan serta bukti suatu pernyataan yang ada di dalam soal, deskripsinya pun singkat namun pembuktiannya tepat.

\section{Soal Nomor 3 :}

3. Jika diketahu $\overline{A E} \cong \overline{E B}$ dan $\overline{D E} \cong \overline{E C}$ Benar/salah kalimat berikut dan berikan alasannxa

a. $\overline{A E}=\overline{E B}$

b. $D E=E C$

c. E titik tengah $\overline{A B}$

d. Jika $C D=20$ dan $A B=40$ maka $\overline{B E} \cong \overline{C D}$

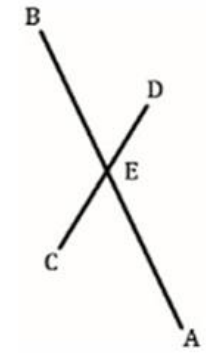

3.) a.) Benar, karena dari diketahui dari soal

b.) Salah, Scharusnya $\angle D E=\angle E C$ atau $D E \cong E C$

c.) Benar, karena $\overline{A E} \cong \overline{E B}$ dan $\overline{\overline{D E}} \cong \overline{E C}$

d.) Benar, karena $E$ adaldh titik tengah dan $\overline{B E} \cong \overline{C D}$ 
Berdasarkan jawaban yang diberikan oleh subjek B pada soal nomor 3, untuk soal bagian a terlihat subjek B kurang baik dalam memberikan alasan serta buktinya, hal ini terlihat bahwa jawaban yang diberikan oleh subjek B yang menyatakan kalimatnya benar karena diketahui dari soalnya itu jawaban yang salah, karena jawaban yang benar itu kalimatnya bernilai salah, jadi untuk pemberian buktinya pun tidak ada.

Selanjutnya untuk soal bagian b jawabannya kurang tepat, karena ukuran sudutnya tidaklah sama, yang benar yaitu $\overline{D E} \cong \overline{E C}$ maka $\mathrm{DE}=\mathrm{EC}$, jadi kalimatnya bernilai benar. Kemudian pada bagian c jawaban dari subjek B sudah tepat, serta pemberian alasannya juga tepat. Yang terakhir pada bagian $\mathrm{d}$ jawabannya tepat namun alasannya kurang tepat, karena $\overline{B E}$ tidak memiliki titik tengah, dan seharusnya menjawabnya dengan menggunakan perhitungan sehingga didapat $\mathrm{CD}=\mathrm{BE}$ maka $\overline{B E} \cong \overline{C D}$. Jadi pada intinya subjek B pada tahap ini masih banyak kesalahan menjawab, dan kurangnya pemberian alasan, bukti, serta pemberian solusi.

\section{Soal Nomor 4 :}

4. Diketahui $A B C$ merupakan sudut tumpul, ukuran sudut $A B D>$ ukuran sudut $A B C$ Buktikan jika ABD merupakan sudut tumpul.

4.) $u \angle a b c=90^{\circ}, u \angle A B D>u \angle A B C$ berarti $u \angle A B D>90^{\circ}$, maka $\angle A B D$ merupakan
Sxdut tumpul.

Gambar 9. Jawaban Subjek B Soal Nomor 4

Berdasarkan jawaban yang diberikan oleh subjek B pada soal nomor 4, terlihat bahwa subjek B hanya memberikan alasan dan bukti dari pertanyaan dalam soal, tidak memberikan dugaan atau memberikan ilustrasi gambar sudutnya, namun sudah disertai penarikan kesimpulan, tetapi ada sedikit kesalahan bahwa sudut tumpul merupakan sudut yang ukurannya $>90^{\circ}$ maka seharusnya ukuran sudut $\mathrm{ABC}$ seharusnya $>90^{\circ}$. 


\section{Soal Nomor 5}

5. Diketahui sudut $P Q R, \overline{Q T}$ garis bagi sudut $P Q R, \overline{Q U}$ garis bagi sudut $P Q T$, Jika ukuran sudut $P Q U=18^{\circ}$, maka ukuran sudut $P Q R=\ldots$

5.) $D_{Q}^{T}$ maka ukuran $\angle P Q R$ adalah $72^{\circ}$

\section{Gambar 10. Jawaban Soal Nomor 5 Subjek B}

Berdasarkan jawaban yang diberikan oleh subjek B pada soal nomor 5, terlihat bahwa subjek B tidak menggunakan manipulasi matematik, jawaban yang diberikan pun tidak disertakan penjelasan spesifik, hanya disertai ilustrasi gambar, seharusnya disertai dengan alasan atau bukti, serta perhitungan yang jelas, subjek C sepertinya sudah mengenal sifat dari garis bagi namun tidak memberikan penjelasan lengkap. Jadi pada tahap ini subjek B kurang mampu dalam menyelesaikan soal yang diberikan.

\section{Deskripsi jawaban dari subjek C (Angkatan 2019)}

\section{Soal Nomor 1 :}

1. Dari gambar disamping, sebutkan segitiga-segitiga yang tergambar tersebut! Serta sebutkan yang mana yang merupakan segitiga:

i) lancip

ii) siku-siku

iii) tumpul

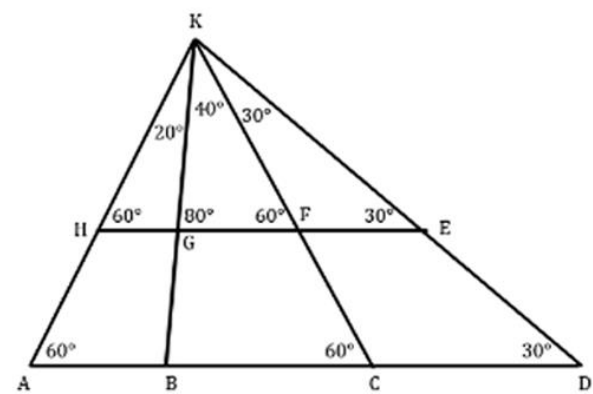

$$
\begin{aligned}
& \text { i. Seritipa lancip : } \triangle E F k, \triangle H F K, \triangle E E K, \triangle A C K, \triangle B C K, \triangle B D K \\
& \text { ii. SikL-sikU: } \triangle A D K, \triangle H E K \\
& \text { iii. tumPUl : } \triangle H E K, \triangle F E K, \triangle A B K, \triangle C O K
\end{aligned}
$$

\section{Gambar 11. Jawaban Subjek C Soal Nomor 1}

Berdasarkan hasil jawaban yang diberikan oleh subjek $\mathrm{C}$ pada soal nomor 1, terlihat bahwa dalam gambar hanya diberikan sebuah segitiga, namun ada beberapa garis bagi, sehingga sebuah segitiga itu terbagi bagi menjadi beberapa bagian segitiga. Dalam soal ini subjek $\mathrm{C}$ sudah dapat menyebutkan beberapa bagian dari segitiga berdasarkan gambar, dan membedakan mana saja yang merupakan segitiga lancip, segitiga siku siku, dan segitiga tumpul secara tepat. 
Pada tahap visualisasi ini subjek $\mathrm{C}$ sudah sangat baik dalam melihat bentuk serta mudah mengetahui apa yang termuat didalam gambar.

\section{Soal Nomor 2 :}

2. Beri alasan mengapa segitiga dibawah ini disebut segitiga siku-siku sama kaki.

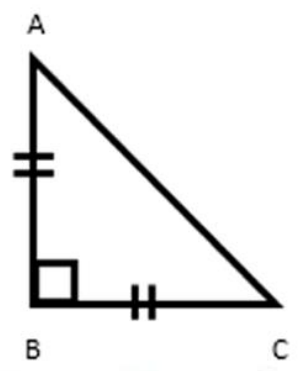

kanena moritiki sebvah sosut sikv-sikv $\left(90^{\circ}\right)$ Yakni di sueut $B$. Dan mempunzai dva sisi Yohg sama paniang yakni sisi $\overline{A B}$ dan $s \bar{B} \overline{B C}$.

\section{Gambar 12. Jawaban Subjek C Soal Nomor 2}

Berdasarkan hasil jawaban yang diberikan oleh subjek C pada soal nomor 2, terlihat bahwa subjek C sudah dapat menganalisis soal dengan baik, memberikan alasan dengan baik serta dapat memberikan bukti kebenaran, deskripsinya pun cukup singkat, tidak bertele tele, namun tepat. Artinya subjek C sudah baik dalam tahap analisis.

\section{Soal Nomor 3 :}

3. Jika diketahu $\overline{A E} \cong \overline{E B}$ dan $\overline{D E} \cong \overline{E C}$ Benar/salah kalimat berikut dan berikan alasannya

a. $\overline{A E}=\overline{E B}$

b. $D E=E C$

c. E titik tengah $\overline{A B}$

d. Jika $C D=20$ dan $A B=40$ maka $\overline{B E} \cong \overline{C D}$

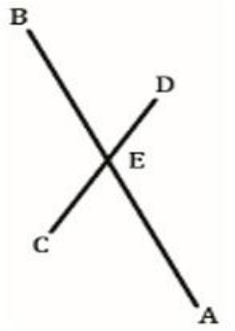

a. $\overline{A E}=\overline{E B}$, benar katena $\overline{A E} \cong \overline{E B}$

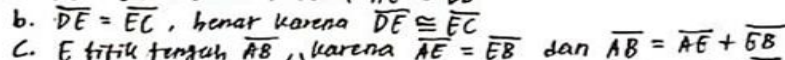

c. E titik tengech $\overline{A B}, \underbrace{}_{B \text { enar }} \overline{A E}=\overline{E B}$ dan $\overline{A B}=\overline{A E}+\overline{\overline{A B}}$ Definisi $1.13 \quad \frac{A B}{A B}=2 \overline{A E}$

E adalat titik tengoh $\overline{A B}$

d. Jike $\overline{C D}=20$ dan $\overline{A B}=40$, make $\overline{B E} \simeq \overline{C D}$, benter karma

$$
\begin{array}{ll}
\overline{A B}=2 \overline{B E} & \overline{B E}=20 \\
\frac{\overline{A B}}{2}=\overline{B E} & \overline{C D}=20 \\
\frac{40}{2}=\overline{B E} & \overline{B E} \cong \overline{C D} \\
\frac{\overline{B E}}{\overline{B E}}=20 &
\end{array}
$$

Gambar 13. Jawaban Subjek C Soal Nomor 3 
Berdasarkan hasil jawaban yang diberikan oleh subjek $\mathrm{C}$ pada soal nomor 3, pada bagian a, subjek C menyatakan jika kalimatnya benar, seharusnya kalimatnya salah, karena $\overline{A E}$ dan $\overline{E B}$ (dibaca segmen $\mathrm{AE}$ dan segmen $\mathrm{EB}$ ) merupakan himpunan titik yang berlainan, sehingga yang benar $\mathrm{AE}=\mathrm{EB}$ artinya panjang $\mathrm{AE}=$ panjang $\mathrm{EB}$, dan seharusnya segmen dinyatakan dalam simbol kongruen $(\cong)$, jadi kalimatnya bernilai salah. Untuk bagian b jawabannya benar namun ada sedikit salah dalam penulisan, karena seharusnya $\mathrm{DE}=\mathrm{EC}$, maka $\overline{D E} \cong \overline{E C}$.

Untuk bagian c dan d juga sama halnya dengan bagian $b$, ada sedikit kesalahan dalam penulisan, maksudnya kesalahan disini karena antara $D E$ dan $\overline{D E}$ merupakan hal yang berbeda, karena jika DE menyatakan nilainya atau panjangnya, sedangkan $\overline{D E}$ menyatakan segmennya, pada intinya jika ada bar diatasnya, berarti menyatakan segmennya, dan jika kedua segmen sama besar atau sama panjang, artinya segmen tersebut kongruen. Meskipun ada beberapa salah penulisan, namun subjek $\mathrm{C}$ sudah cukup baik dalam memberikan alasan dari jawaban yang ditulisnya, dalam menyatakan benar salahnya juga cukup baik namun dalam memberikan solusi sepertinya kurang, karena dalam jawabannya kalimatnya bernilai benar semua, jadi tidak terlihat pemberian solusinya. Pada tahap abstraksi ini subjek C sudah cukup baik dalam menjawab soal yang diberikan, juga cukup mampu memperoleh intisari konsep dari segmen.

\section{Soal Nomor 4 :}

4. Diketahui $A B C$ merupakan sudut tumpul, ukuran sudut $A B D>$ ukuran sudut $A B C$ Buktikan jika ABD merupakan sudut tumpul.

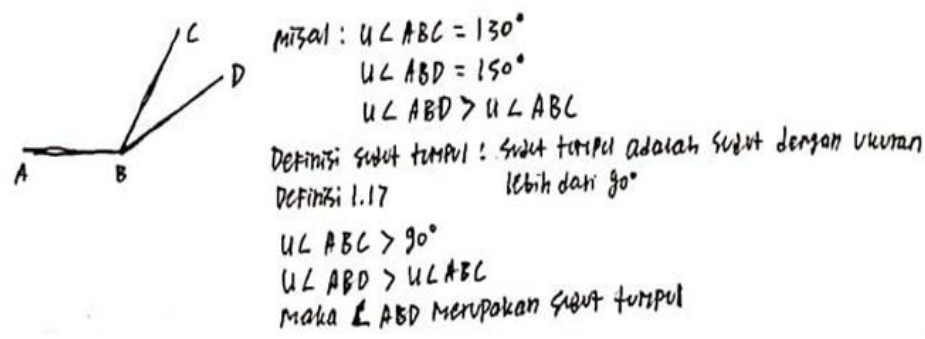

Gambar 14. Jawaban Subjek C Soal Nomor 4 
Berdasarkan hasil jawaban yang diberikan oleh subjek C pada soal nomor 4, subjek $\mathrm{C}$ dapat mengajukan dugaan yaitu dengan menggambarkan bentuk sudutnya, serta memberi permisalan ukuran sudutnya, dapat memahami sifat yang dilengkapi dengan definisi jika sudut tumpul merupakan sudut yang besarnya > $90^{\circ}$. Subjek C juga dapat memberikan bukti spesifik jika sudut yang lebih besar dari sudut tumpul berarti sudut tumpul juga. Pada tahap deduksi formal ini subjek C dapat memberikan kesimpulan dari pernyataan umum, yang menyatakan jika sudut tumpul merupakan sudut yang besarnya $90^{\circ}$, ke pernyataan khusus, yang menyatakan jika ukuran sudut $\mathrm{ABC}>90^{\circ}$, ukuran sudut $\mathrm{ABC}>$ ukuran sudut ABD, maka ABD merupakan sudut tumpul. Jadi pada tahap ini subjek $\mathrm{C}$ sudah baik dalam memberikan bukti, mengajukan dugaan, serta menarik kesimpulan dari pernyataan.

\section{Soal Nomor 5 :}

5. Diketahui sudut $P Q R, \overline{Q T}$ garis bagi sudut $P Q R, \overline{Q U}$ garis bagi sudut $P Q T$, Jika ukuran sudut $P Q U=18^{\circ}$, maka ukuran sudut $P Q R=\ldots$

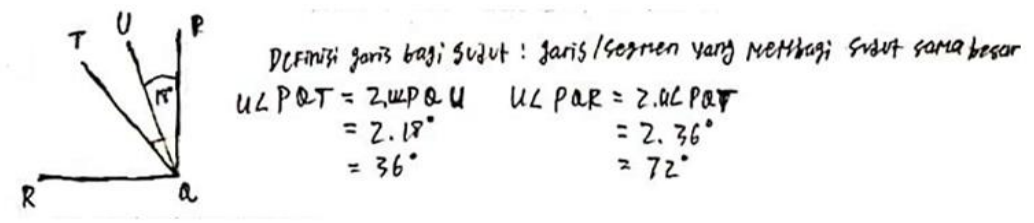

Gambar 15. Jawaban Subjek C Soal Nomor 5

Berdasarkan hasil jawaban yang diberikan oleh subjek C pada soal nomor 5, subjek $\mathrm{C}$ dapat melakukan manipulasi matematik dari apa yang diperoleh di dalam soal, serta dapat mengajukan dugaan dengan menggambarkan bentuk sudutnya dan garis baginya, namun gambarnya seperti sudut siku siku. Selanjutnya subjek $\mathrm{C}$ juga dapat menemukan sifat dari garis bagi sudut dengan memberikan definisi garis bagi sudut di dalam jawabannya sehingga dapat mempermudah pemahaman dalam memberi penjelasan, penjelasan yang diberikan cukup singkat, namun perhitungannya tepat dan akurat karena diperkuat oleh definisi garis bagi sudut, namun pada tahap ini subjek $\mathrm{C}$ kurang dalam memberikan generalisasi, hal ini dapat dilihat dalam jawaban pada saat sudah menemukan nilai ukuran sudut $\mathrm{PQR}$ sebesar $72^{\circ}$, subjek $\mathrm{C}$ tidak memberikan 
kesimpulan secara umumnya, untuk jawabannya sudah cukup baik serta jawabannya pun benar.

\section{SIMPULAN}

Kesimpulannya subjek A dan $\mathrm{C}$ sudah berada pada tingkat 5 (Rigor) berdasarkan teori Van Hiele, terlihat dari jawaban-jawaban subjek yang semua soalnya dapat dikerjakan dengan tepat walaupun masih ada beberapa kesalahan dalam menjawab atau kurangnya bukti untuk menjawab soal yang diberikan dan untuk tingkat penalaran matematisnya pun sudah sangat baik, serta untuk subjek B berada di tingkat 4 (Deduksi Formal) karena dalam menjawab soal nomor 5 nampaknya subjek B masih belum mampu memberikan alasan, bukti serta perhitungan yang spesifik. Dan juga hampir semua indikator penalaran matematis yang ada sudah terpenuhi oleh ketiga subjek.

\section{DAFTAR PUSTAKA}

Adamura, F., \& Susanti, V. D. (2018). Penalaran Matematis Mahasiswa dengan Kemampuan Berpikir Intuitif Sedang dalam Memecahkan Masalah Analisis Real. 6(2), 77-92.

Agustin, R. D. (2016). Kemampuan Penalaran Matematika Mahasiswa Melalui Pendekatan Problem Solving. PEDAGOGIA: Jurnal Pendidikan, 5(2), 179.

Fertiwi, Y., Margiati, K. ., \& Suryani. (2013). Pengaruh Teori Belajar Van Hiele Terhadap Hasil Belajar Geometri Siswa SD. Jurnal PGSD, 1(1), 1-11.

Hodiyanto, H. (2018). Kemampuan spasial sebagai prediktor terhadap prestasi belajar geometri mahasiswa. Jurnal Mercumatika: Jurnal Penelitian Matematika Dan Pendidikan Matematika, 2(2), 59.

Konita, M., Asikin, M., Sri, T., \& Asih, N. (2019). Kemampuan Penalaran Matematis dalam Model Pembelajaran Connecting, Organizing, Reflecting, Extending. Prisma, 2, 611-615.

Kusumawardani, D. R. (2018). Pentingnya Penalaran Matematika dalam Meningkatkan Kemampuan Literasi Matematika. 1, 588-595.

Mahfudy, S. (2017). Strategi Pembuktian Matematis Mahasiswa Pada Soal Geometri. JTAM | Jurnal Teori Dan Aplikasi Matematika, l(1), 31. 
Mikrayanti, M. (2016). Meningkatkan Kemampuan Penalaran Matematis Melalui Pembelajaran Berbasis Masalah. Suska Journal of Mathematics Education, 2(2), 97.

Nadhifa, N., Maimunah, M., \& Roza, Y. (2019). Analisis Kemampuan Pemecahan Masalah Siswa pada Materi Bangun Ruang Sisi Datar. NUMERICAL: Jurnal Matematika Dan Pendidikan Matematika, 63-76.

Nasional, P. S. (2009). Deskripsi kesulitan belajar geometri mahasiswa program studi pendidikan matematika fakultas keguruan dan ilmu pendidikan universitas cokroaminoto palopo. 03, 273-283.

Sukirwan, Darhim, D., \& Herman, T. (2018). Analysis of students' mathematical reasoning. Journal of Physics: Conference Series, 948(1).

Yuliana, D., \& Ratu, N. (2019). Analisis Keterampilan Dasar Visual Geometri Siswa SMP Ditinjau Berdasarkan Level Berpikir Analisis Van Hiele. Jurnal Cendekia : Jurnal Pendidikan Matematika, 3(2), 536-549.

Yuliana, M., \& Wiryawan, S. A. (2018). Developing Learning Instruments of Geometry Based on Van Hiele Theory to Improving Students ' Character Developing Learning Instruments of Geometry Based on Van Hiele Theory to Improving Students ' Character. 